\title{
Adolphe Quetelet, the Average Man and the Development of Economic Methodology ${ }^{1}$
}

\section{Bert Mosselmans ${ }^{2}$}

\begin{abstract}
Quetelet's contribution to statistics has received adequate attention in Stigler (1986, 1999) and Porter's (1986) seminal works on the history of that scientific discipline. ${ }^{3}$ Our contribution investigates Quetelet's influence on economic methodology. Other scholars have already investigated his influence on econometrics and empirical economics (Morgan 1990, Stigler 1999), but we argue that his influence on theoretical economics should be considered significant as well. We devote attention to Quetelet's concept of the 'average man'. For this purpose we briefly summarize Quetelet's methodology and examine the evolution of his ideas as expressed in his published works. We then investigate his influence on classical political economy, on Jevons's 'calculus of pleasures and pains' and on the debates of the 'Methodenstreit'. We conclude with some considerations on contemporary discussions in macroeconomics about the 'representative individual'. We argue that the history of statistics, and especially Quetelet's contribution, should not be neglected by historians of economic thought as it provides important insights into the development of economic methodology.
\end{abstract}

\footnotetext{
${ }^{1}$ Previous versions of this paper have been presented at the meeting of the Dutch-Flemish Society of the History of Economic Thought, 7 December 2001, Antwerp; at the $29^{\text {th }}$ Meeting of the History of Economics Society, Davis CA, 5-8 July 2002; and at lunch seminars in Antwerp and Bristol. I would like to thank Christos Baloglou, Tony Brewer, Edmund Cannon, Annie Cot, Guido Erreygers, Charles Figuieres, Pat Gunning, Albert Jolink, Mary Morgan, Wilfried Parys, Renee Prendergast and Michael V. White for useful comments and suggestions.

${ }^{2}$ University of Antwerp, Faculty of Applied Economics Ufsia-Ruca, Prinsstraat 13, B-2000 Antwerp, Belgium; and University of Bristol, Department of Economics, 8 Woodland Road, Bristol BS8 1TN, United Kingdom. E-mail: Bert.Mosselmans@chello.be, WWW home page: home.tvd.be/cr27486/. The author gratefully acknowledges support of the Speical Research Fund of the University of Antwerp.

${ }^{3}$ See also Westergaard (1932:167-170), Klein (1997:122-131).
} 


\section{Adolphe Quetelet (1796-1874)}

Lambert Adolphe Jacques Quetelet was born in Gent, Belgium, on 22 February $1796 .{ }^{4}$ He studied at the lycée in Gent, where he started teaching mathematics in 1815, at the age of 19. In 1819 he moved to the athenaeum in Brussels and in the same year he completed his dissertation (De quibusdam locis geometricis, necnon de curva focal - Of some new properties of the focal distance and some other curves). He became a member of the Royal Academy in 1820. He lectured at the museum for sciences and letters and at the Belgian Military School. His scientific research encompassed a wide range of different scientific disciplines: meteorology, astronomy, mathematics, statistics, demography, sociology, criminology and history of science. He made significant contributions to scientific development, but he also wrote several monographs directed to the general public. He founded the Belgian Observatory, founded or co-founded several national and international statistical societies and scientific journals, and presided over the first series of the International Statistical Congresses. Bartier (1977) argues that Quetelet was a liberal and an anticlerical, but no atheist or materialist nor a socialist. In 1855 Quetelet suffered from apoplexy, which diminished but did not end his scientific activity. He died in Brussels on 17 February 1874. An impressive amount of correspondence survives and is kept in various archives. ${ }^{5}$

Quetelet's published work includes collected data on meteorological phenomena and on population. He developed his theory of the 'average man' in several monographs. We will devote our attention to (1) his Sur l'homme et le développement de ses facultés, ou essai de physique sociale 6 (Treatise on Man, first published in 1835 in Paris, reprinted in 1836 in Brussels, translated into German in 1838, into English in 1842 and into Russian in 1865) ${ }^{7}$; (2) his Lettres à S.A.R. le duc régnant de Saxe-Cobourg et Gotha, sur la théorie des probabilités, appliquée aux sciences morales et politiques (Letters on Probability, 1846, English translation 1849); and (3) Du système social et des lois qui le régissent, 1848. Later works do not contain fundamentally new ideas that are substantial for the

\footnotetext{
${ }^{4}$ It is not my intention to give an exhaustive biography. More information is provided by Lottin (1912:1-103).

${ }^{5}$ See Wellens-De Donder (1966) for an exhaustive index of Quetelet's correspondence.

${ }^{6}$ See Freund (1977) for a discussion of Comte versus Quetelet. Porter (1986:41) argues that Quetelet 'pirated' Comte's concept of 'physique sociale', although he departed radically from positivism.

${ }^{7}$ This first main work is in fact a collection of earlier published papers and studies.
} 
development of economic methodology. The second edition of his Treatise (1869), entitled Physique sociale ou essai sur le développement des facultés de l'homme (Physique Sociale), is not very different from the first edition; and Anthropométrie ou mesure des différentes facultés de l'homme, 1871, is largely confined to the physical development of man.

\section{The Development of the 'Average Man'}

In his introduction to Sur l'homme Quetelet argues that the 'Science of Man' should devote attention to the 'numerical appreciation of the facts' related to physical and moral phenomena of mankind. Since individual peculiarities are infinite, investigating the isolated individual would lead to a generalization of what is entirely accidental. The separation of constant causes and accidents can only be achieved when a sufficient number of observations have been collected. The same causes will then always lead to the same effects, implying that moral phenomena resemble physical phenomena when observed at a large scale. It would be possible to establish laws, but they would not be invariable, as they would change 'with the nature of the causes producing them'. Moreover, those laws would only be applicable to individuals within certain limits. The 'social body' is the object of the science of man, and not 'the peculiarities distinguishing the individuals composing it'. Only a few men of superior genius are able to alter society sensibly. Man is influenced by numerous causes, such as his organization, education or knowledge, means or wealth, institutions and local influences; some of them are physical, others have a moral nature. Individuals exercise 'disturbing actions' or 'secular perturbations' upon their environments, the effects of which arise however very slowly. It would be necessary to abstract from these forces at first and return to them when sufficient data has been collected. This process would lead to the construction of the 'social man', a fictitious being, similar to the center of gravity within natural objects. The 'science of man' should distinguish between what belongs to the 'equilibrium' of the system and what belongs to the 'movement' of the system, but the center of gravity of the system and the direction of the movement remain unknown (Quetelet 1835:2949, 1842:5-9). It is important to emphasize that Quetelet does not study distributions (like Galton, Pearson and others would do a few decades later), but outer limits and averages instead. Stigler (1986:171-172) argues that in the development of Quetelet's thought a shift in emphasis can be observed from the outer limits within which the fictitious center of gravity moves, towards an investigation of the center itself. 
Sur l'homme starts with physical characteristics of mankind and devotes special attention to rates of birth and death. Quetelet presents a considerable amount of statistical data, but his discussion of fundamental and accidental causes is not very convincing and gives a rather speculative impression. ${ }^{8}$ Porter (1986:46) points out that Quetelet's empirical and theoretical work is largely unconnected. On the one hand Quetelet collects and arranges an impressive amount of statistical data. On the other hand he develops an 'extravagant system of metaphors' to link the social domain to the theories and mathematics of the natural sciences. Both Porter (1986) and Stigler (1986) show that Quetelet's data are not always very accurate - which is not surprising, since he is one of the pioneers of systematical data collection. Moreover, in his haste to get things published he is not very critical towards his sources and he hardly ever checks his calculations. Porter (1986:55) argues that Quetelet's lasting contribution is more abstract, as he builds a case for concentrating on statistical information presented by a larger whole, instead of devoting attention to concrete causes of individual phenomena. This is especially important for social phenomena of a moral nature, such as criminality. In his Sur l'homme he introduces the notion 'propensity to crime' (penchant au crime) to discuss the probability that an individual will commit crime (taking the influence of season, climate, sex and age into account) (Quetelet 1835:421, 1842:82).

The goal of these investigations is to determine the 'average man', which should precede every other investigation of society. This average man would be specific to every individual nation and also to every individual historical epoch. Quetelet argues that there is evolution and development during the history of mankind, but at the same time he maintains that all faculties that are not based on science remain essentially stationary. The factor of change is human intelligence. Intelligence is growing continuously, thereby triggering scientific development (which is obviously cumulative according to Quetelet). But there is more: all characteristics that are related to intelligence will therefore change as well; Quetelet makes explicit reference to both physiological and moral features. Examples include the statement that the facial structure of the 'Caucasian' looks most promising for high intelligence and the

\footnotetext{
${ }^{8}$ The reader will probably agree with me that this is an example where Quetelet jumps hastily to conclusions: 'It is also very remarkable, that marriages only become frequent when men have passed the stormy period of the passions, and of the greatest tendency to crime, which happens about the 24th year: this is also the time when the development of the physical qualities has terminated, and the intellectual ones attain a greater energy' (Quetelet 1842:16).
} 
observation that the moral quality of 'courage' has become less important since ancient times (Quetelet 1842:98, 100). Mankind is growing towards intellectual, physiological and moral perfection and the 'average man' is the archetype of this perfection: 'I have said before, that the average man of any one period represents the type of development of human nature for that period; I have also said that the average man was always such as was conformable to and necessitated by time and place; that his qualities were developed in due proportion, in perfect harmony, alike removed from excess or defect of every kind, so that, in the circumstances in which he is found, he should be considered as the type of all which is beautiful - of all which is good' (Quetelet 1842:100).

Not only does intelligence increase as the 'average man' grows up; the limits within which the different elements relating to man oscillate also get narrower (Quetelet 1842:108). This implies that people become ever more indistinguishable in the course of history and that 'monstrosities', defined as everything that exceeds the observed limits, will disappear. Quetelet holds that 'great men' in every state of society (like Pythagoras, Archimedes, Kepler and Newton) come very close to the ideal of the 'average man'. They impersonate the mind of the nation like nobody else does, but at the same time they distinguish themselves from others because of their genius. Great men unify particularity and generality. This apparent contradiction does not seem to bother Quetelet at all. If the 'great man' really is the impersonation of the 'average man', how is it possible that he has a high level of 'particularity'? This particularity can only be seen as a collection of accidental features, which is opposed to the conception of the 'average man' as consisting of general features only. The equivalence between 'average' and 'perfect' seems however sensible in the context of medical science, where Quetelet finds inspiration to develop an analogy. The physician has an idea of what constitutes normal or perfect health, and individuals that exceed certain limits are considered unhealthy and are in need of treatment (Quetelet 1842:99). But would the 'average man' not just have an average intelligence, making it therefore implausible to consider him as an ideal and certainly not as a genius?

These issues become more clarified in his Letters on Probability, where Quetelet makes reference to Aristotle's conception of the 'right mean' in his discussion of average and limits (Quetelet 1846:59-63). For example, Aristotle's conception of generosity is the 'right mean' in between of waste and avarice (Aristotle 1968:1107a28-32, 1106b37-1107a10). In Du système social Quetelet uses the concept center moral (Quetelet 1848:107). The average is then the natural state, and deviations in both possible directions should be considered harmful monstrosities as soon as they exceed certain limits. 
Quetelet distinguishes between a real average (moyenne) and an arithmetical average (moyenne arithmétique). Whereas the real average has an existence in reality, the arithmetical average is a number that refers to something fictional, averaging quantities over a group of homogeneous but clearly different objects. Averaging different measurements of the height of one particular house leads to the height of that particular house, a real average; averaging different measurements of different houses in the same street, leads to the height of a fictional house, an arithmetical average (Quetelet 1846:64-69). A further example of arithmetical averages is Quetelet's discussion of the general rise of the price of corn between 1817 and 1842. Two conclusions arise from this discussion: first, money is progressively losing its value; second, the limits within which the corn price fluctuates become ever more narrow. Quetelet argues that narrower limits are beneficial and that sudden price changes should be avoided: a rising corn price leads to a higher rate of mortality, whereas a falling corn price is harmful for the producers. He is in favor of increased corn imports, but not, like Ricardo, because this would counteract the falling rate of profit, but simply because this would increase price stability and narrow the limits of price fluctuations. The fact that this process of narrowing can actually be observed in the statistical data from 1817 to 1842 , is explained by increased knowledge, institutional wisdom and political calm (Quetelet 1846:70-73). The tendency of narrower limits, which is equivalent to the tendency to realize the 'arithmetical average', thereby transforming it into a 'real average', is thus a direct result of growing intelligence and the cumulative nature of science. Porter (1986:46-49) argues convincingly that Quetelet prefers the 'mean' in social and political settings because this would resolve social conflicts, and that this preference can be explained by taking Quetelet's own experiences following the Belgian revolution of 1830 into account. ${ }^{9}$

In Sur l'homme Quetelet emphasizes that a meaningful calculation of averages presupposes a large number of observations. Only then the different 'accidents' will cancel each other out. This process of statistical enquiry leads to the determination of definite causes that will lead to the same effects as long as the causes exist. ${ }^{10}$ The relative stability of these causes over time is explained by the

\footnotetext{
${ }^{9}$ See Cooper \& Murphy (2000) for Quetelet's reliance on aesthetic notions when constructing the 'average man'.

${ }^{10}$ In his Letters Quetelet elaborates on causes, distinguishing constant, variable and accidental causes. Whereas constant causes act in a continuous manner, accidental causes show no regularity at all. Variable causes act continuously as well, but with regularly changing tendencies (Quetelet 1846:157-
} 
very little influence individuals have to alter their environment, and even if they succeed it takes much time before all effects become visible. Only few men gifted with 'superior genius' can alter sensibly the social state, but even their influence is limited (Quetelet 1842:6-7). But then, how can the existence of these men with 'superior genius' be reconciled with narrower limits and the equivalence between 'average' and 'perfect' man? One explanation could be that intelligence is neither measurable nor comparable, and that it therefore does not enter into the conception of the 'average man'. Although Quetelet does not develop a theory of the IQ, he does discuss the possibilities of measuring intelligence. $^{11}$ To solve the apparent contradiction we encountered above, only one reasonable explanation seems possible: a person is a 'genius' because he resembles the 'average man' so closely, and precisely this recognition makes him an outstanding and therefore particular individual. ${ }^{12}$ The process of narrower limits, accompanied by growing indistinguishability of individuals, should therefore lead to more genius in the population. This is everything but inconsistent with Quetelet's belief in growing intelligence and cumulative scientific development, as we discussed earlier. Quetelet must however have sensed that the concept of 'intelligence' caused a particular problem for his 'average man', as he wrote a (very short) chapter on 'intelligence' in his Du système social (1848). Here he argues that intelligence is a combination of nature and nurture and that true genius can emerge only when both elements are unified. Most ordinary students know more about nature than Archimedes did,

160). Here and elsewhere it is clear that Quetelet is inspired by meteorology, another scientific discipline to which he contributed thoroughly.

${ }^{11}$ Porter (1986:45) argues that Quetelet proclaimed the universality of the rule of numbers, 'Mundum regunt numeri'. Quetelet's discussion of the measurement of intelligence remains however largely unsuccessful. He discusses examination results and the influence of age on intellectual development, and makes some superficial references to the intermixture of physical, moral and intellectual faculties of man (Quetelet 1848:114-142).

${ }^{12}$ It is clear that this statement does not remove, but incorporate the contradiction. Particularity is here defined as being universal. Many philosophers will not like this statement, to say the least. Here Quetelet is inspired by Victor Cousin, who was influenced by Hegel. Only 'great individuals' would be able to change the world sensibly, and those 'great individuals' are inspired by the 'hidden spirit' of their age. This explains why precisely 'average' individuals are most suitable for this task. See Lottin (1912) and Prendergast (1997). 
but this does not make them geniuses; and potential geniuses that do not receive adequate education will also not contribute to scientific development. The chapter confirms that Quetelet identifies degree of intelligence with degree of resemblance to the average man, as he expresses the hope that 'phrenology' will someday be able to measure intelligence directly (Quetelet 1848:114-142). Intelligence is then similar to good health and stupidity equal to sickness. True genius can then only emerge if someone with a high degree of resemblance to the 'average man' receives an adequate education, which may explain the scarcity of these beings. In any case, Quetelet's identification of average and ideal remains problematic, especially in the moral and intellectual spheres, as many subsequent critics of his theory will point out. It is also no surprise to see that most of the measurements he discusses relate to physiological aspects of the average man.

Quetelet's view on the development of civilization also implies that the ideal of the 'average man' would become approximated ever more closely as time goes by, thereby bringing him effectively into existence. The ontological position of the 'average man' is also strengthened when Quetelet observes that, in practice, it is often impossible to distinguish a 'real' from an 'arithmetical' average. If a not particularly highly skilled person would perform 5738 different measurements of one and the same individual, the graphical representation of the data would look similar to the graphical representation of measurements of 5738 different individuals. According to Quetelet this counts as evidence that we can really talk about a 'type' of man (Quetelet 1846:133-138). Moreover, the number of people reaching or exceeding extraordinary limits - in his examination of body lengths - is so small that their probabilities can almost be neglected (Quetelet 1846:149-156). Quetelet feels therefore confident with his 'type' of man. The 'type' differs however from nation to nation, implying that there is no real universal average man: 'chaque race d'homme a son type particulier' (Quetelet 1846:139-148). I would argue that Quetelet's ontological position is similar to Aristotle's: the 'type' is an 'essence' that does not exist as a concrete being, but it exists in every concrete individual that deviates from this 'essence' in a higher or a lesser degree. The statistician can determine this 'type' if he takes a sufficiently large amount of observations into account, as the 'accidents' would cancel each other out and the average would approximate the 'type'. We could say, rephrased in terms of distributions, that the identification of 
average and ideal therefore rests on the presupposed existence of a type around which all individuals are distributed normally. ${ }^{13}$

For Quetelet the 'average man' is thus an ideal that should be approached as closely as possible. But it is also an empirical result, reached by averaging (a large number of quantities observed in certain groups, thereby characterizing those groups with certain average physical and moral features or propensities. Those empirical results allow social scientists to compare different groups with each other, and also to establish relationships between specific magnitudes. Although Quetelet knows very well that it is not possible to derive conclusions from statistical laws for concrete individuals, some probabilistic relations may be established. For instance, the 'propensity to crime' reaches a maximum at the age of 25 years; it is four times higher for men than for women; and in the summer most crimes against people are committed (in the winter, most crimes against properties) (Quetelet 1835:484-486).

Despite his use of the concept 'social physics', Quetelet never developed a thorough theory of social forces, but rather a collection of speculative explanations for relationships between certain quantities. Later sociologists, such as Durkheim, were primarily interested in underlying social forces and therefore critical towards Quetelet and his 'average man' (Porter 1995:21). Desrosières (1997) argues that Durkheim's work explains why Quetelet became forgotten after 1920 (together with criticisms such as Halbwachs (1913) and the Methodenstreit (see below), as well as the works of Galton, Pearson, Yule and Fisher, focusing on distributions rather than on averages). ${ }^{14}$ He argues that because of Durkheim "the statistical mean has been returned to the realm of methodological

\footnotetext{
${ }^{13}$ See also Armatte \& Droesbeke (1997). The authors hold that Quetelet is therefore co-responsible for 'le dogme de la loi normale' that dominated the second half of the 19th century.

${ }^{14}$ See also Desrosières (1993). MacKenzie (1981:9) argues that Quetelet had but little direct impact on the development of statistics in Britain. Goldman (1991) argues however that Quetelet was a 'catalyst' for the British statistical movement. Especially three ideas were important: the regularity of social phenomena was demonstrable by the use of statistical analysis; even in the 'moral realm' there were regularities 'of the order of physical facts'; and these regularities stemmed from social conditions rather than from aggregated individual wills. These developments were important for the establishment of a "predictive science of society which could rationally explain human behavior in the aggregate".
} 
individualism, and the 'collective type' is no longer assimilated into the 'average type"' (Desrosières 1997:184). ${ }^{15}$ The 'collective type' would represent the ideal citizen whereas the 'average type' would be the arithmetical result derived from egoistic individuals, implying that both should be seen as completely different. It is however beyond doubt that Quetelet and his 'average man' influenced 19th century social science, and economics in particular, thoroughly. ${ }^{16}$

\section{Quetelet and classical political economy}

Quetelet's influence on classical political economy was very limited, if not non-existent, for several reasons. Many important classics, such as Smith and Ricardo, died long before Quetelet's works became published and widely known. The use of statistical material was very uncommon in the beginning of the $19^{\text {th }}$ century. If data was used at all, then mainly for the purpose of illustrating theoretical positions, rather than proving them. ${ }^{17}$ Thomas Malthus is an exception, since his Essay on Population makes extensive use of population data (although the figures are certainly not always accurate). Both Malthus and Quetelet were interested in population data and they met in 1833 . Together with Jones and Babbage they established the statistical section of the British Society for the Advancement of Science (Lottin 1912:61). ${ }^{18}$ Malthus also supported Quetelet's efforts to undertake the first scientific census in Belgium. But besides those statistical endeavors, Quetelet does not seem to have influenced classical political economy. ${ }^{19}$

15 "La moyenne statistique est repatriée dans l'univers de l'individualisme méthodologique, et le 'type collectif' n'est plus assimilé au 'type moyen"' (my translation).

${ }^{16}$ But also historical science: Buckle (1858) was inspired by Quetelet when he wrote his History of Civilization in England.

${ }^{17}$ This is also the case for Marx, who refers occasionally to Quetelet. See Horvath (1977).

${ }^{18}$ More information about the foundation of this section, later called 'section F', is provided by Henderson (1997:29-33).

19 A detailed investigation of all classical economists would go beyond the scope of this paper. According to Scazzieri (1987) the late Russian Ricardian Nikolai Ivanovich Ziber was influenced by Quetelet. Scazzieri's account is not entirely clear to me: “Ziber (...) examine[s] Ricardo's theory from an original point of view, in which attention is focused on the 'macro-social' laws governing a community founded on division of labor, rather than on the allocative criterion ensuring mutual 


\section{From 'average man' to 'trading body': William Stanley Jevons}

Jevons was dissatisfied with classical political economy, as Ricardo and Mill "shunted the car of Economic Science on to a wrong line", whereas authors such as Malthus and Senior had "a far better comprehension of the true doctrines" (Jevons 1879:lvii). Jevons would like to establish a new 'canon' of the history of economics, descending from a revised Adam Smith, and moving through Malthus and Senior to the new generation of mathematical economists (Mosselmans 2000). It is quite remarkable that precisely Malthus and Senior are the ones that Quetelet corresponded with. ${ }^{20}$

consistency of individual actions. The statistician and social scientist Lambert-Adolphe Quételet [sic] provides Ziber with the idea that the study of political economy ought to be based on a method of inquiry radically different from the one suitable to the study of the economic behavior of individual units" (Scazzieri 1987:30-31). The argument that Ricardo would study "economic behavior of individual units' seems to be a 'neoclassical' misinterpretation of Ricardo. Ziber's criticism seems to be directed toward Smith's argument that the 'invisible hand' would co-ordinate individual behavior at the aggregate level. Since I do not know Russian, I am unfortunately unable to investigate whether this is Ziber or Scazzieri's interpretation. In any case, Quetelet seems to have inspired Ziber to devote attention to 'social averages' and 'macro-social' observations.

${ }^{20}$ Jevons' preference for Malthus and Senior does not seem to stem from their statistical activity, but from their anticipation of certain core ideas concerning marginal utility. Jevons argues that "Ricardo has [not] the slightest claim to the theory [of rent], as it was quite as well stated by Malthus if not by Anderson long before" (Black 1977b:146). He also praises Senior for using the concept of 'rent' in a more general manner, as a revenue derived from the possession of a natural agent (including, for instance, extraordinary talents) (Black 1977d:68, Senior 1836:128-130). Jevons recognizes that a generalization of the theory of rent leads directly to marginalism, as this "theory of a distinctly mathematical character (...) seems to give a clue to the correct mode of treating the whole science" (Jevons 1879:vi). Moreover, Jevons argues that Nassau Senior develops a 'true theory of economy' with his argument that 'utility' is not an intrinsic quality, but the expression of a relationship (Black 1981:79-80). Senior (1836:6) remarks that the word 'utility' has been "sanctioned by Mr. Malthus". 
It is beyond doubt that Jevons knows the writings of Adolphe Quetelet very well and that his methodology is influenced thoroughly by the 'average man' ${ }^{21}$ On 2 August 1857 Jevons purchases Quetelet's Treatise on Man (1842). Almost exactly one year later, on 4 August 1858, he writes to his sister Henrietta that he is working on a project that looks very similar to Quetelet's 'science of man': "It seems to me that Man is a subject as little understood now as the Heavens (Astronomy) were by the Ancients. Within the last hundred years, sciences almost innumerable have sprung up, but mostly devoted to physical Nature. Comparatively few have perceived that Human Nature may also be the subject of a science. It is indeed a many-sided subject. Religion, metaphysics, ethics, jurisprudence, political economy, politics, and even, medicine, art, poetry and many other studies all have man for the subject. But the social condition of man as influenced by the many internal and external circumstances is perhaps an indefinite but a wide and rich field for further research" (Black 1973:335-336). In another letter to his sister, dated 30 January 1859, he makes very clear that he is inspired by Quetelet: "All the investigations of Social Science must proceed on the assumption that there are causes to make people good and bad, happy and miserable, rich and poor, as well as strong and feeble. It follows that each individual man must be a creature of cause and effect. This has indeed been argued by Quetelet, a German [sic], but requires yet to be more completely proved" (Black 1973:361-362). Although it is unclear why Jevons believes that Quetelet is German, it is clear that his 'science of man' project is inspired by his reading of the Treatise on Man.

In his Principles of Science Jevons refers several times to Adolphe Quetelet. ${ }^{22}$ He reports that the 'theory of comparative frequency of divergence from an average, was first adequately noticed by Quetelet' (Jevons 1877:188), describes Quetelet's experiment on probability (Jevons 1877:208) and elaborates on his 'law of error' (Jevons 1877:378-385). All references are to Quetelet's Letters on

\footnotetext{
${ }^{21}$ Michael White comments that Jevons did not only read Quetelet directly, but also discussions that appeared in the Sydney Magazine of Science and Art and Herschel's review article.

${ }^{22}$ Schabas $(1990: 18,161 n 44)$ recognizes that Quetelet's influence on Jevons was important. She argues that Jevons borrowed his ideas about average (individuals) and the fictitious mean from Quetelet, but that he failed to acknowledge the source, and therefore he probably forgot about Quetelet. Although this would be compatible with Jevons's odd idea about Quetelet being a German, he does refer to the Letters on Probability, where Quetelet's ideas about real and arithmetical averages are explained more systematically than in the Treatise on Man.
} 
Probability, including the one in the important sections on mean and average (Jevons 1877:360-365). Jevons prefers the use of 'mean' when Quetelet's real average (moyenne) is concerned (the approximation of a definite existing quantity) and 'average' or 'fictitious mean' when an arithmetical average (moyenne arithmétique) is dealt with. The fictitious mean is important, since it allows us to 'conceive in a single result a multitude of details' ${ }^{23}$ Jevons repeats Quetelet's example of the center of gravity within a body and elaborates on the distinction between cases in which an invariable center is present and those in which it is not. In the second edition of his Theory of Political Economy Jevons refers to his discussion of 'fictitious means' when he defines a 'trading body' (Jevons 1879:95-98): 'By a trading body I mean, in the most general manner, any body either of buyers or sellers (...) Every trading body is either an individual or an aggregate of individuals, and the law, in the case of the aggregate, must depend on the fulfillment of law in the individuals' (Jevons 1879:95-96). Jevons equates aggregate and average consumption: provided that the community under consideration is large enough, the average consumption of the aggregate community will vary continuously due to price changes, whereas individual behavior is strongly affected by accidents. If the individuals had exactly the same features (those relevant for consumption), then the average laws of supply and demand would be equal to the conduct of every individual. ${ }^{24}$ If however the 'powers, wants, habits, and possessions' of different people were widely different, then the average would not represent 'the character of any existing thing'. The accidents would cancel each other out and a certain 'typical' consumer would emerge. Although this is clearly a case of a fictitious mean, it would not be less useful: 'the

${ }^{23}$ Reiss (2001) proposes to replace Jevons's distinction between real mean and fictitious mean by a distinction between 'natural' economic quantities and 'merely measurable economic quantities', the difference being whether they are or are not explained by causal models. This implies that "natural quantities' come up when there is a 'tight fit between theory and measurement'. It sounds however contradictory to make the 'natural' status of a quantity dependent on its explanation by a model. The use of different concepts seems to be recommended here, and Reiss' interpretation deviates strongly from what Jevons (and Quetelet) had in mind.

${ }^{24}$ White (1989) shows that Jevons regarded the 'laws of supply and demand' as an empirical matter. Each law expresses a specific relationship between a (group of) consumer(s) and a good. 
movements of trade and industry depend upon averages and aggregates, not upon the whim of individuals' ${ }^{25}$

Jevons thus recognizes that people are not homogeneous and that it would be wrong to create 'representative agents' depicting individual behavior. In the case of large aggregates however, disturbing causes would cancel each other out. Here Jevons applies Quetelet's large number argument, and he extends it further to the idea that large trading bodies (or the economy as a whole) do not depend upon individual accidents. If however specific policy questions are at stake, the heterogeneity of different societal subgroups has to be accounted for. Jevons uses the concept of 'character' in order to bridge the gap between universal theory and characteristics of specific subgroups in society (White 1994a, 1994b). White argues that Jevons's work was not directed to the explanation of the behavior of specific individuals per se, unless these individuals were representative for all market participants of a certain uniform character. The science of economics deals with the lowest motives, and the Theory contains 'representative individuals', which behave in the way required by the Theory. All economic actors do not have to behave in exactly the same way, but disturbing causes would balance and

${ }^{25}$ In Mosselmans (1998) I argue that Jevons's use of the 'fictitious mean' in general and the 'trading body' in particular fits into the framework of Jevons's logic in terms of extent of meaning, which implies that all logical terms should be developed until they refer to individuals. Quetelet's principle of the 'fictitious mean' allows Jevons to depict aggregates of individuals as individuals as well. White (2001) shows that Jevons's concept of 'trading bodies' should be placed within the context of the debates over 'the laws of supply and demand' following William Thornton's On Labor (1869). Jevons argued that the problem of commodity indivisibility, that would lead to a failure of the equations of exchange, could be 'imagined' non-existent by lessening the size of the commodity indefinitely. If this argument was taken for granted, the concept of 'trading body' could then be used in a very broad way as the 'principles of exchange' would be the same in all cases. Although this argument demonstrates why Jevons thought that the concept of 'trading bodies' was appropriate, it does not explain its origin. White argues that the term 'body' is derived from natural philosophy, as Jevons refers to the 'gravitational metaphor'. This paper demonstrates that Jevons derived this metaphor from Quetelet and justified its use by Quetelet's 'large number' argument. This is, of course, not incompatible with White's 'indeterminacy in exchange' argument. 
therefore the 'representative individual' may be an appropriate model for the Theory. ${ }^{26}$ The theory is however indeterminate in cases when more information is required. For example, it is unclear whether an increase in the real wage rate, proportionate to an increase in labor productivity, results in increased or reduced hours of work. More information about the 'character' of the person under consideration is required: whereas 'learned professionals' might be expected to work harder, 'lower class people' might prefer idleness over labor and prefer greater 'ease' in the case of rising real incomes. The 'representative individual' of the Theory is linked to class and race behavior by 'facts' expressing the 'character' of the class or race under consideration, and the Victorian middle-class is used as a yardstick for evaluation (White 1994a). The conceptions of 'character' and 'race' are therefore similar to the 'type' of the average man that Quetelet discusses. By investigating a specific group of human beings (a specific class or 'race'), the existence of a specific 'type' is presupposed and described quantitatively by the outcome of statistical operations.

\section{War on Two Fronts: the Average Man and the 'Methodenstreit'}

Quetelet's statistical works are also discussed by several members of the German historical school. Adolph Wagner's principal statistical work Die Gesetzmässigkeit in den scheinbar willkührlichen menschlichen Handlungen vom Standpunkte der Statistik (1864) devotes a lot of space to Quetelet, the "first living statistician in Europe" (Wagner 1864:6). Wagner embraces Quetelet's argument that moral laws become visible when a large number of observations has been taken into account, and that this does not conflict with the existence of individual free will (Wagner 1864:7-10). Wagner insists that the statistical method is valid only when the numbers are derived from a group forming an organic whole. "We must rather restrict ourselves to interconnected groups of people that, like the population of a town, a province, a state or a whole nation, form an organically interconnected whole, linked through numerous strings of material, spiritual and mental relations, and therefore consist of homogeneous parts" (Wagner 1864:15). ${ }^{27}$ Like Quetelet, Wagner presupposes the existence of the

\footnotetext{
${ }^{26}$ White (1994a:434) acknowledges that Jevons was influenced by Quetelet's argument that human behavior was normally distributed. White (1994b) investigates the influence of Richard Jennings on Jevons's representation of behavior in mechanical and functional form.

27 "Wir müssen uns vielmehr an zusammengehörige Menschengruppen halten, welche, wie die Bevölkerung einer Stadt, einer Provinz, eines Staates, wie eine ganze Nation ein organisch
} 
'type' and believes that the statistician can discover this 'type'. He emphasizes however that statistically established 'laws' are merely regularities that are established inductively, but justified deductively from the fundamental proposition that effects are proportional to causes. Since numerous different causes are operating on society, regularities should be carefully dealt with. The regularity as such does not explain reality (Wagner 1864:63-80). ${ }^{28}$

The German Historical School does not categorically reject Adolphe Quetelet's conception of the 'average man'. Statistical methods are helpful when studying historical development of the economy and society. Wagner (1864:XIII-XIV) argues that the aversion towards statistics results from insufficient 'sense of number' (Zahlensinn). This 'sense of number' is predominantly absent among

zusammengehörendes Ganze bilden, das durch zahllose Fäden materieller, geistiger und gemüthlicher Beziehungen unter sich verknüpft ist, und so aus homogenen Bestandtheilen besteht” (my translation).

${ }^{28}$ Finding laws is therefore possible as such, without learning more about the inner nature of the causes" (Wagner 1864:66). ("Die Auffindung von Gesetzen ist daher auch an sich denkbar, ohne dass dadurch über das innere Wesen der Ursachen ein weiterer Aufschluss gewonnen wird”, my translation). The stability in the propensity to crime is an example of a regularity: the accidental causes cancel each other out and the fundamental (material, spiritual, moral and economic) causes remained unchanged (Wagner 1864:77). The relevant causes therefore include economic, spiritual and moral relations (or institutions). Wagner's adoption of the 'average man' has been criticized in a review, signed "B.", and published in the Jahrbücher in 1865. The reviewer objects to Wagner's use of the concept of statistical 'laws' and argues that they should rather be seen as features of specific groups of individuals, expressed in numbers. He also objects to the idea of 'propensities', as this expresses the statement that something of the aggregate must be contained in the individual. This is an elaborate criticism of the 'average man' (and his Aristotelian ontological status). The 'average man' is just an average and it is unclear where he comes from and what he signifies and the propensity (Impuls) is just a construction of the mind and nothing real (B 1965:291). Statistical regularities are not laws, as this would require that we derive the laws from collective individual behavior (i.e. "wie fangen es die Kreidewesen an, um den Kreidekreis zu bilden?") (B 1865:292). But even if it is taken for granted that the 'average man' makes sense, then the question arises how many observations must be made. Simply taking the average leads to a stable number, even if no general or common causes are present. There is also no guarantee that individual causes will cancel each other out. 
women, poets and speculative scientists. Held (1867) argues that the followers of Quetelet's methodology are pursuing, in a more sophisticated quantitative manner, Adam Smith's original research program. Held highlights the historical and institutional considerations in The Wealth of Nations to argue that Adam Smith really was a predecessor of the historical method in economics. He reproduces several quotations in which Smith discusses 'ordinary' features of laborers, which he seems to equate with 'average' characteristics. This leads Held to the conclusion that the 'proto-historical' Smith makes a more or less implicit use of Quetelet's 'average man'. Whereas Smith remained too silent about this conception, Quetelet exaggerated its use, which implies that the correct method of applying the 'average man' lies in between of both authors. Held's criticism of Quetelet is directed to the latter's transmission of the 'average man' to larger communities and even humanity as a whole. Knapp's (1872) criticism is much more elaborate. ${ }^{29}$ Knapp's general idea amounts to the claim that Quetelet simply transposes scientific principles from the natural sciences (astronomy in particular) to the realm of the social sciences. The 'average man' is a scientific construct that responds, through the principle of cause and effect, to quasi-physical forces enacting upon him. Specific historical circumstances and existing institutions are not taken into account by this approach, making it therefore inadequate for the study of society. The historical school therefore welcomes Quetelet and his statistics since it is compatible with the empirical and inductive approach to economics, but condemns his 'overshooting' that arises from treating the study of society as a natural science through the application of the 'average man'.

Remarkably, Knapp's criticism of Quetelet is similar to the views of the Austrian school. Hayek (1952) argues that Quetelet's work led to the belief that statistics was the only legitimate method in the study of society. Hayek condemns, like Knapp, the transmission of methods from the natural sciences to society and argues that Quetelet's - and Comte's - works should be seen as 'general endeavors to find natural laws of the development of the human race as a whole, to extend the Laplacean conception of universal determinism to cultural phenomena, and to make mass phenomena the sole object of the science of society' (Hayek 1952:357-358). Taking Quetelet's limited theoretical achievements into account, this criticism seems to be exaggerated, but his rhetoric certainly contributed to the development of the statistical methodology in economics. In any case, it is clear that the

${ }^{29} \mathrm{Knapp}$ (1871) is an extensive review of Quetelet's writings that prepared his 1872 appraisal of Quetelet as a theoretician. 
'average man' is diametrically opposed to the subjectivist approach of Austrian methodological individualism. ${ }^{30}$ Attempts to re-homogenize authors such as Jevons and Menger based on the recognition that both take uncertainty into account (Peart 1998) are therefore neglecting fundamental methodological differences.

\section{From Micro to Macro: the Average Man as Representative Individual}

Hartley $(1996,1997)$ argues that the representative agent was born in Marshall's Principles of Economics. Prendergast (1997) objects that at least two earlier approaches can be detected: Frédéric Le Play examined small numbers of representative families and Victor Cousin equated representative man with the agent of historical development. ${ }^{31}$ In any case, it is clear that the notion of 'representative agents' already appears in Jevons's Theory of Political Economy, where it is derived from Quetelet's writings on the 'average man'. Although Marshall created his notion of the 'representative firm' to abstract from the idiosyncrasies of individual firms, it certainly is not a statistical construct. ${ }^{32}$ Hartley (1996, 1997:9-18) shows that Marshall's 'representative firm' is a very limited notion and that it was criticized thoroughly and abandoned quickly. Marshall also decided against applying his construct to consumer theory. However, in recent decades the 'representative agent' reappeared in the quest for microfoundations for macroeconomics (Hartley 1997:19-30).

The contemporary discussion about 'representative individuals' seems to be similar to the historical discussion of the 'average man'. Kirman (1992) argues that the construction of 'representative individuals' to explain macroeconomic phenomena results from the need to develop 'satisfactory' microfoundations for macroeconomics. The belief that microeconomics developed an adequate model of individual behavior (maximization under constraints) led to the wish to represent macro-models by the behavior of a representative maximizing individual. Even if it is granted that problems of co-ordination are not at stake, Kirman questions what the representative individual actually represents. There is no guarantee that the aggregate of maximizing individuals is itself a maximizer; there is no guarantee that, due to a policy change, the representative behavior would react

\footnotetext{
${ }^{30}$ For a general Austrian criticism of the 'science is measurement motto', see Mises (1949:350-358).

${ }^{31}$ It cannot be established with certainty that Marshall was influenced by Cousin. Quetelet certainly was influenced by Cousin (see footnote 11).

${ }^{32}$ Groenewegen (1995:168) notes that Marshall preferred Le Play's to Quetelet's methodology.
} 
in the same way as the aggregate would; and the choices of the representative behavior do not have to coincide with the aggregate choices of the individuals. For this last point, Kirman constructs an example where the aggregate of two individuals with different indifference curves and identical budget constraints would prefer $\mathrm{x}$ over $\mathrm{y}$, whereas the 'representative individual' would prefer $\mathrm{y}$ to $\mathrm{x}$. Representing aggregate by individual behavior constrains the analysis as it eliminates the possibility to introduce more complex dynamics (such as provided by game theory).

This discussion sounds similar to Jevons's definition of a 'trading body', especially where he argues that the fulfillment of the law in the aggregate depends on the fulfillment of law in the individuals. Kirman, on the contrary, argues that fulfillment of the law in the individuals does not guarantee fulfillment of the law in the aggregate. We must however keep in mind that, according to Jevons, the aggregate or the average 'individual' would be established using statistical data, with disturbing causes canceling each other out. In his discussion the representative agent does not behave according to a general microeconomic theory, since the 'character' of the societal group under consideration has to be taken into account. For Jevons induction and deduction are inverse processes (Jevons 1877:11-12). The discussion of the 'representative agent' in macroeconomics, on the contrary, amounts to the imposition of a model for an individual to the aggregate level. I doubt that Jevons would have agreed with this procedure. The criticism of the 'Methodenstreit' on both sides also holds true: the 'representative agent' procedure both neglects institutions and is incompatible with subjective methodological individualism.

\section{Conclusion}

Quetelet's average man seems to be back in business. Originally the average man simply expressed numerical relationships between statistical data. Quetelet did not use the average man as a model to explain individual behavior, but as a yardstick to measure deviations from this presupposed ideal. ${ }^{33}$ The deviations should be minimized in order to promote stability and diminish monstrosities. Jevons argued that the aggregate and the average are the same. The aggregate could be treated as an individual, provided the 'character' of the individuals involved would be taken into account. Jevons justified this 'empirical procedure' with the erroneous argument that disturbing causes would cancel each other out, which is nothing else than shifting from the normal distribution of errors towards the

\footnotetext{
${ }^{33}$ For more information about Jevons and measurement, see Maas (2001).
} 
normal distribution of observations. The average man, born in Belgium in 1835, appears again in contemporary discussions in macroeconomics. He has however somehow been reversed: whereas Quetelet and Jevons proceeded from data about individual behavior towards aggregate behavior, contemporary economists use a model of individual behavior to describe aggregate behavior. $19^{\text {th }}$ century economists such as Quetelet, Jevons and Wagner presuppose the existence of a specific 'type' for a certain group of individuals and collect and analyze data to describe this 'type' in a quantitative manner. $20^{\text {th }}$ century macroeconomists impose a 'type' of rational economic behavior on a group of individuals to describe aggregate behavior. The theories developed by Quetelet and Jevons, flawed as they may appear from today's point of view, urge us to keep specific characteristics of groups of individuals into account. The 'average man' of a specific group does not 'by definition' conform to the ideal of economic rationality as expressed in microeconomic models of behavior. Moreover, critical thinkers such as Held and Knapp argue that historical and institutional circumstances must be taken into account when studying aggregates of individuals. People are embedded in an 'organic whole': even if it is taken for granted that the 'maximizing model' can be imposed on all beings, the 'representative individual' would still fail to take those aspects into account. Those aspects include coordinating mechanisms, but also objective and subjective institutions that influence aggregate behavior. We conclude that the contemporary discussion concerning 'representative individuals' would benefit from a re-examination of 'old' $19^{\text {th }}$-century economics.

A somewhat ironic general conclusion can be drawn from this comparison between the 'average man' debates in the $19^{\text {th }}$ century and the 'representative agent' discussions in the $20^{\text {th }}$ century. Social scientists such as Quetelet and Jevons wanted to examine large groups of individuals and societies as a whole. They relied on a 'balancing disturbing causes' methodology justified by a 'large numbers' argument. Behind this discourse an Aristotelian ontology is hidden, already presupposing a certain 'type' that is characteristic for a specific group. The presupposed 'type' is of course the main problem for this approach. There is no guarantee that the 'average man' is more than just an average and it is illegitimate to assume a normal distribution of observations because of a normal distribution of errors. The contemporary 'representative agent' methodology, on the other hand, presupposes that aggregate behavior can be described by the individual behavior of a representative agent. Proponents of this approach try to explain aggregate behavior by (idealized) individual behavior. Advocates of the 'average man', on the contrary, tried to examine aggregate behavior directly, abstracting from 
'idiosyncratic' properties of individuals. In both cases a 'type' is presupposed: the 'average man' with 'essential' Aristotelian characteristics or the 'representative agent' as an ideal maximizing individual. Quetelet tried to get rid of the individual in order to explain the aggregate. The 'representative agent' reintroduces the individual as a means to explain the aggregate. In both cases there is no guarantee that the 'type' is adequate to represent the aggregate. Is it really impossible to study the aggregate without making reference to (a certain type of) individual behavior? Hartley (1997:200-204) thinks that macroeconomics will become more limited in scope, discussing only parts of the macroeconomy, and taking imperfect information, bounded rationality and interdependencies into account. There is always a loss of information when moving from the individual to the aggregate and back. A heterogeneous group of individuals cannot be represented by an ideal average man, just as the behavior of an aggregation of heterogeneous individuals cannot be represented by a model of idealized individual behavior.

\section{References}

Aristotle. (1968). The Nichomachean Ethics. Collected Works Vol.XIX. London: Heinemann.

Armatte, M. \& J.-J. Droesbeke. (1997). "Quetelet et les probabilités: le sens de la formule." In: Actualité et universalité de la pensée scientifique d'Adolphe Quetelet. Brussel: Académie Royale de Belgique, pp. 107-135.

B. (1965). "Die Gesetzmässigkeit in den scheinbar willkürlichen menschlichen Handlungen vom Standpunkte der Statistik. Von Dr. Adolph Wagner. Hamburg, Boyes und Geisler, 1864.” Jahrbücher für Nationalökonomie und Statistik 4:286-301.

Bartier, J. (1977). "Quetelet politique." In: Adolphe Quetelet 1796-1874. Mémorial Adolphe Quetelet No. 4. Brussel: Palais des Académies, pp. 20-45.

Black, R. D. C. (ed.) (1973). Papers and Correspondence of William Stanley Jevons Volume II. Correspondence 1850-1862. London and Basingstoke: MacMillan.

--- (ed.) (1977a). Papers and Correspondence of William Stanley Jevons Volume III. Correspondence 1863-1872. London and Basingstoke: MacMillan.

--- (ed.) (1977b). Papers and Correspondence of William Stanley Jevons Volume IV. Correspondence 1873-1878. London and Basingstoke: MacMillan. 
--- (ed.) (1977c). Papers and Correspondence of William Stanley Jevons Volume V. Correspondence 1879-1882. London and Basingstoke: MacMillan.

--- (ed.) (1977d). Papers and Correspondence of William Stanley Jevons Volume VI. Lectures on Political Economy 1875-1876. London and Basingstoke: MacMillan.

--- (ed.) (1981). Papers and Correspondence of William Stanley Jevons Volume VII. Papers on Political Economy. London and Basingstoke: MacMillan.

Black, R. D. C. \& R. Könekamp (eds.) (1972). Papers and Correspondence of William Stanley Jevons Volume I. Biography and Personal Journal. London and Basingstoke: MacMillan.

Buckle, H. (1858). History of Civilization in England Volume I. London: John W. Parker

Cooper, B. P. \& M. S. Murphy (2000). "The Death of the Author at the Birth of Social Science: the Cases of Harriet Martineau and Adolphe Quetelet." Studies in the History and Philosophy of Science 31(1):1-36.

Desrosières, A. (1993). La Politique des grands nombres. Paris: La Découverte.

--- (1997). "Quetelet et la sociologie quantitative: du piédestal à l'oubli." In: Actualité et universalité de la pensée scientifique d'Adolphe Quetelet. Brussel: Académie Royale de Belgique, pp. 179-198.

Freund, J. (1977). "Quetelet et Auguste Comte." In: Adolphe Quetelet 1796-1874. Mémorial Adolphe Quetelet No. 4. Brussel: Palais des Académies, pp. 46-64.

Goldman, L. (1991). "Statistics and the Science of Society in Early Victorian Britain. An Intellectual Context for the General Register Office." Social History of Medicine 4(3):415-434.

Groenewegen, P. (1995). A Soaring Eagle: Alfred Marshall 1842-1924. Aldershot: Edward Elgar.

Halbwachs, M. (1913). La théorie de l'homme moyen. Essai sur Quetelet et la statistique morale. Paris: Félix Alcan.

Hartley, J. E. (1996). “The Origins of the Representative Agent.” Journal of Economic Perspectives 10(2):169-177.

--- (1997). The Representative Agent in Macroeconomics. London: Routledge.

Hayek, F. [1952] (1979). The Counter-Revolution in Science. Studies on the Abuse of Reason. Indianapolis: Liberty Press.

Held, A. (1867). “Adam Smith und Quetelet.” Jahrbücher für Nationalökonomie und Statistik 9:249279. 
Henderson, P. (1997). Early Mathematical Economics. William Whewell and the British Case. Lanham, Boulder, New York \& London: Rowman \& Littlefield.

Horvath, R. A. (1977). "Quetelet et Marx. Essai de synthèse de leurs pensées au point de vue statistique et sociologique." In: Adolphe Quetelet 1796-1874. Mémorial Adolphe Quetelet No. 4. Brussel: Palais des Académies, pp. 87-99.

Jevons, W. S. [1877] (1913). The Principles of Science. A Treatise on Logic and Scientific Method. Reprint of second edition with corrections. London: MacMillan and Co.

--- [1879] (2001). The Theory of Political Economy. Second Edition. Writings of Economics Volume

2. London: MacMillan.

Kirman, A. P. (1992). “Whom or What Does the Representative Individual Represent?" Journal of Economic Perspectives 6(2):117-136.

Klein, J. (1997). Statistical Visions in Time. A History of Time Series Analysis 1662-1938. Cambridge: Cambridge University Press.

Knapp, G. F. (1871). "Bericht über die Schriften Quetelets zur Sozialstatistik und Anthropologie.” Jahrbücher für Nationalökonomie und Statistik 17:167-174, 342-358, 427-445.

--- (1872). “A. Quetelet als Theoretiker.” Jahrbücher für Nationalökonomie und Statistik 18:89-124.

Lottin, J. (1912). Quetelet. Statisticien et sociologue. Leuven \& Paris: Institut Supérieur de Philosophie \& Félix Alcan.

Maas, H. (2001). Mechanical Reasoning: Jevons and the Making of Modern Economics. Proefschrift Universiteit van Amsterdam.

MacKenzie, D. A. (1981). Statistics in Britain 1865-1930. The Social Construction of Scientific Knowledge. Edinburgh: Edinburgh University Press.

Michotte, P. (1904). Etudes sur les théories économiques qui dominèrent en Belgique de 1830 à 1886. Leuven: Charles Peeters.

Mises, L. [1949] 1996. Human Action. Irvington: Foundation for Economic Education.

Morgan, M. S. [1990] (1995). The History of Econometric Ideas. Cambridge: Cambridge University Press.

Mosselmans, B. (1998). "William Stanley Jevons and the Extent of Meaning in Logic and Economics." History and Philosophy of Logic 19:83-99. 
--- (2000). "Cracking the Canon: William Stanley Jevons and the Deconstruction of 'Ricardo'." in: Psalidopoulos, M. (ed.) The Canon in the History of Economics : Critical Essays. London: Routledge, pp. 127-145.

Peart, S. (1998). 1998. "Jevons and Menger Re-Homogenized? Jaffé after 20 Years." American Journal of Economics and Sociology 57(3):307-25.

Porter, T. M. (1986). The Rise of Statistical Thinking: 1820-1900. Princeton: Princeton University Press.

--- (1995). "Statistical and Social Facts from Quetelet to Durkheim." Sociological Perspectives $38(1): 15-26$.

Prendergast, R. (1997). “The Representative Agent.” Journal of Economic Perspectives 11(4):231233.

Quetelet, A. [1835] (1991). Sur l'homme et le développement de ses facultés, ou essai de physique sociale. Paris: Bachelier.

--- (1836). Sur l'homme et le développement de ses facultés, ou essai de physique sociale. Brussel: Louis Hauman.

--- [1842] (1968). A Treatise on Man and the Development of his Faculties. Edinburgh, reprinted New York: Burt Franklin.

--- (1846). Lettres à S. A. R. Le Duc Régnant de Saxe-Cobourg et Gotha, sur la théorie des probabilités, appliquée aux sciences morales et politiques. Brussel: M. Hayez.

--- (1848). Du système social et des lois qui les régissent. Paris: Guillaumin.

--- (1869). Physique sociale ou Essai sur le développement des facultés de l'homme. Brussel: Muquardt.

--- (1871). Anthropométrie ou mesure des différentes facultés de l’homme. Brussel, Leipzig \& Gent: C. Muquardt.

--- (1873). Congrès international de statistique. Brussel: F. Hayez.

--- (1914). Soziale Physik oder Abhandlung über die Entwicklung der Fähigkeiten des Menschen. Jena: Gustav Fischer.

Reiss, J. (2001). "Natural Economic Quantities and their Measurement." Journal of Economic Methodology 8(2):287-311.

Scazzieri, R. (1987). “Ziber on Ricardo.” Contributions to Political Economy 6:25-44. 
Schabas, M. (2000). A World Ruled by Number. William Stanley Jevons and the Rise of Mathematical Economics. Princeton, New Jersey: Princeton University Press.

Senior, N. W. [1836] (1951). An Outline of the Science of Political Economy. New York: Augustus M. Kelly.

Stigler, S. M. (1986). The History of Statistics. The Measurement of Uncertainty before 1900. Cambridge, MA \& London: Belknap Press of Harvard University Press.

--- (1999). Statistics on the Table. The History of Statistical Concepts and Methods. Cambridge, MA \& London: Harvard University Press.

Wagner, A. (1864). Die Gesetzmässigkeit in den scheinbar willkührlichen menschlichen Handlungen. Hamburg: Boyes \& Geisler.

Wellens-De Donder L. (1966). Inventaire de la correspondance d'Adolphe Quetelet. Brussel: Palais des Académies.

Westergaard, H. (1932). Contributions to the History of Statistics. London: King \& Son.

White, M. V. (1989). "Why Are There No Supply and Demand Curves in Jevons?" History of Political Economy 21(3):425-56.

--- (1994a). "Bridging the Natural and the Social: Science and Character in Jevons's Political Economy." Economic Inquiry 32:429-44.

--- (1994b). "The Moment of Richard Jennings: the Production of Jevons's Marginalist Economic Agent." In: Mirowski, P. (ed.) Natural Images in Economic Thought. Cambridge: Cambridge University Press, 197-230.

--- (2001). "Indeterminacy in exchange: Disinterring Jevons's trading bodies." The Manchester School 69: (2) 208-226.

Word count (excl. endnotes): 7.692

Key words: Quetelet, Jevons, Wagner, average, representative individuals Date of the manuscript: 25.07 .2002 